\title{
Cosmogenic Nuclide Data Sets from the Sierra Nevada, California, for Assessment of Nuclide Production Models: I. Late Pleistocene Glacial Chronology
}

\author{
Fred M. Phillips ${ }^{1}$
}

\author{
${ }^{1}$ New Mexico Institute of Mining \& Technology, Department of Earth \& Environmental \\ Science, Socorro, NM 87801, USA (phillips@nmt.edu)
}

\section{Abstract}

The Cosmic-Ray prOduced NUclide Systematics on Earth Project (CRONUS-Earth Project) has reused a limited number of 'legacy, ${ }^{10} \mathrm{Be}$ and ${ }^{36} \mathrm{Cl}$ samples from late Pleistocene moraines in the Sierra Nevada for the testing and evaluation of cosmogenic nuclide production rates derived by the CRONUS-Earth Project.A secure glacial chronology for the range is necessary for this purpose. Evidence for the timing of glacial fluctuations is provided by direct radiocarbon ages marking glacial termini at various times and by chronologies on lacustrine cores, marine cores, and speleothem records. Evaluation of these records yields a relatively consistent picture. Tioga 3 glaciers were close to their maximum extent from $>20$ to about $17 \mathrm{ka}$. Close to $17 \mathrm{ka}$ they retreated rapidly, then began to readvance at $\sim 16.8 \mathrm{ka}$. The Tioga 4 readvance culminated at about $16.2 \mathrm{ka}$ and rapid retreat ensued, with the equilibrium line altitude rising by $400 \mathrm{~m}$ by $15.7 \mathrm{ka}$ and the range probably virtually ice-free by a short time thereafter. There is no 
evidence of ice readvance until the Recess Peak glaciation. Dating of this readavance is inconsistent, with direct dates on glacial features and some lacustrine and speleothem records placing it between 14.0 and $13.0 \mathrm{ka}$, but many regional records are more consistent with an advance duringthe interval 13.0 to $12.6 \mathrm{ka}$. After consideration of all the evidence I have assigned ages of $15.75 \pm 0.5 \mathrm{ka}$ for Tioga 4 retreat and $13.3 \pm 0.25$ for the maximum extent of the Recess Peak glaciation.

\section{Keywords}

Sierra Nevada, glacial chronology, cosmogenic nuclide production rate, beryllium-10, chlorine-36

\section{Introduction}

Although in principle it is possible to calculate the production rates of terrestrial cosmogenic nuclides from basic physics, in practice it has proved necessary to employ empirical geological calibration sites (Gosse and Phillips, 2001). One of the earliest calibrations reported was for ${ }^{10} \mathrm{Be}$ and ${ }^{26} \mathrm{Al}$ from samples of glacially modified granodiorite from the Sierra Nevada in California, USA (Nishiizumi et al., 1989). This study was published in 1989, but used samples collected in 1986. Similar samples from the Sierra Nevada were used by Evans et al. (1997) to calibrate ${ }^{36} \mathrm{Cl}$ production rates. The Cosmic-Ray prOduced NUclide Systematics on Earth Project (CRONUSEarth Project) was funded by the U.S. National Science Foundation in 2005. The purpose of the CRONUS-Earth Project is to resolve inconsistencies in the theoretical and 
empirical basis for application of terrestrial cosmogenic nuclides in the earth sciences. As part of these activities, new calibrations of ${ }^{10} \mathrm{Be},{ }^{26} \mathrm{Al}$, and ${ }^{36} \mathrm{Cl}$ production are being performed. The CRONUS-Earth Project has selected and sampled a suite of new sites to provide the basis for the calibration (Phillips et al., 2015a). However, it has employed historical calibration and application sites for testing the accuracy of the new calibrations. These include a number of studies previously performed in the Sierra Nevada of California. Use of these sites for this purpose requires knowledge of the actual exposure history of the samples, independent of cosmogenic-nuclide dating.

The previous investigators used the best available knowledge at the time to estimate the exposure history of their samples. However, much new information has become available in the past 25 years. The objective of this paper is to evaluate and synthesize the currently available noncosmogenic data bearing on the deglaciation of the Sierra Nevada between 20 and 10 ka, yielding $\mathrm{a}^{14} \mathrm{C}$-based chronology (with minor Useries) that is independent of cosmogenic-nuclide dating. A second paper (Phillips et al., 2015b) will provide descriptions of the sites and a summary of results and assessment of site-specific influences on the samples.

\section{Sierra Nevada Glacial Chronology}

\subsection{Introduction}

Important syntheses of Sierra Nevada glacial chronology have been published by numerous researchers over the past century (Knopf, 1918; Blackwelder, 1931; Birkeland, 
1964; Gillespie, 1982; Fullerton, 1986; Bursik and Gillespie, 1993; Osborn and Bevis, 2001; Clark et al., 2003; Gillespie and Clark, 2011). The generally accepted terminology and conceptual framework for the glacial sequence of the Sierra Nevada was established by Blackwelder in 1931 (Blackwelder, 1931). He named the McGee, Sherwin, Tahoe, and Tioga glacial stages, although without numerical chronology, as the means for such were lacking in his time. Of these, we need be concerned here with only the Tioga, inasmuch as only samples from the Tioga-age features (and younger Recess Peak age) were collected for use in any of the calibration exercises (Nishiizumi et al., 1989, did inadvertently sample pre-Tioga bedrock, but did not use the samples for calibration).

Research subsequent to Blackwelder's time has established that the Tioga glaciation took place during the interval 30 ka to 15 ka (Benson et al., 1996; Phillips et al., 1996; Menking et al., 1997; Phillips et al., 2009; Rood et al., 2011). For the purpose of establishing the exposure age of the 1986 calibration set, it is the termination of the Tioga glaciation that is pertinent. Scientific understanding of these events has changed considerably since these samples were collected. At that time, the final Tioga glaciers were thought to have retreated close to the very end of the Pleistocene, which was then dated to 10,000 years ago. This disappearance of the Tioga glaciers was thought to have been followed by a series of small-to-medium size advances throughout the Holocene, variously termed Hilgard, Recess Peak, and Matthes (Birman, 1964). The samples for the 1986 study were therefore collected well above the Tioga terminal moraines, in order to be in the strongly erosive basal regime of the glacier (MacGregor et al., 2009), but low enough to be below the presumed Hilgard or other Holocene glacial limit, so that all samples would have been exposed simultaneously by a single major glacial event. 
Nishiizumi et al. (1989) surveyed the radiocarbon age control available at that time for the terminal Tioga retreat. Based on this survey, they concluded that the best estimate for the timing of the retreat was $10,000{ }^{14} \mathrm{C}$ yr ago. Secular variation of ${ }^{14} \mathrm{C}$ activity in the atmosphere was recognized, and based on the limited control then available, Nishiizumi et al. (1989) adjusted the preferred radiocarbon age to 11,000 calibrated years.

\subsection{Current Age Control}

Since 1989 a large amount of new age control, mainly radiocarbon measurements, has been collected on the Tioga glacial retreat and subsequent events. These have led to a major revision of the chronology of terminal Pleistocene events in the Sierra Nevada. Investigations by Clark and Gillespie (1997) demonstrated that there have been only two post-Tioga glacial advances in the range: the Recess Peak and the Matthes. The Recess Peak glaciers advanced only a few thousand years after the Tioga retreat and are therefore very latest Pleistocene rather than Holocene. The Matthes advance was during the late Holocene and culminated during the Little Ice Age. It was much less extensive than the Recess Peak glaciation.

Although cosmogenic exposure ages obviously cannot be used to constrain the chronology for a cosmogenic production rate study, cosmogenic samples can be used to provide context on the general pattern and style of the retreat. Phillips et al. (1996) and (2009) published a large number of ${ }^{36} \mathrm{Cl}$ surface exposure ages from Bishop Creek, within the same region as the ${ }^{10}$ Be calibration study. In the time interval of interest, Phillips et 
al. (2009) distinguished three glacial advances: the Tioga 3 at c.a. 18 ka, Tioga 4 at c.a. 15.5 ka, and Recess Peak at c.a. 12.5 ka. The Tioga 4 glaciers advanced down-canyon only about one-third as far as the Tioga 3 advance. The Recess Peak advance was only about one-tenth that of the Tioga 3. Notably, Phillips et al. (2009) found that samples exposed by the retreat of the Tioga 4 glacier had very similar ${ }^{36} \mathrm{Cl}$ ages, about $15.0 \mathrm{ka}$, regardless of elevation above the Tioga 4 terminal moraines. This indicates that the final Tioga retreat was very rapid, estimated by Phillips et al. (2009) as probably less than 500 years from the initiation of retreat to the complete withdrawal of the glaciers into cirque headwalls. This is consistent with the previous conclusions of Clark (1976), based on geomorphic evidence. This rapid retreat history is advantageous for establishing the chronology of the cosmogenic calibration samples, because the age will be relatively independent of position within the drainage.

I have divided the radiocarbon age control for glacial chronology into two categories: primary and secondary. 'Primary’ data are samples that (fairly) directly date the actual retreat of a Tioga or Recess Peak glacier. Virtually all of these are samples of organic material taken from cores extracted from lakes or bogs beneath the former course of a glacier. Organic carbon will only begin to accumulate after the glacier has retreated past the point in question and renewed plant growth in the newly uncovered drainage allows organic detritus to be deposited in the basin. The ages from such sources are therefore presumably limiting minimum ages for deglaciation. However, in practice they may either pre- or postdate the actual time of deglaciation, significantly in some cases. This is for three reasons. First, there is likely at least a short time lag between deglaciation and the reestablishment of vegetation in the drainage. Typically, a layer of 
organic mud and silt is found overlying coarser sediment consisting of sand and gravel, which is presumed to be terminal glacial outwash. However, the rapid deposition of outwash may continue for some time while the glacier retreats up-valley. Given the rapidity of Tioga glacial retreat (discussed above), it seems likely that this time lag before deposition of dateable organic material is small (perhaps a hundred years or less), but must be considered nevertheless. The second reason is that these kinds of samples have been collected over a wide range of elevations. The ${ }^{10} \mathrm{Be}$ calibration samples of Nishiizumi et al. (1986), as well as the ${ }^{36} \mathrm{Cl}$ samples described above, were collected mostly from quite high elevations in the range, but some of the independent age control was from considerably lower elevation. The Tioga glacier retreated in a pulsed fashion, pulling back from a terminal position, then later readvancing to a somewhat higher position and again retreating(Phillips et al., 1996; Phillips et al., 2009; Rood et al., 2011). Post-glacial sediment samples from low positions along the course of the glacier are therefore expected to yield ages that may predate ones from high elevation within the drainage. The third reason is more methodological. Cores for lacustrine chronologies have commonly been drilled by hand. Practically speaking, this means that the coring is usually abandoned when severe resistance is encountered, in other words, when the first layer of outwash is reached by the auger. The investigators usually assumed that this corresponded to local deglaciation, but given that there may have been significant Tioga and post-Tioga advances upstream, outwash may have been transported down-canyon and deposited at lower elevations in episodes postdating the local deglaciation. These three considerations indicate that at any elevation a range of basal radiocarbon ages may 
be measured, but generally the oldest should be preferred as most closely constraining the age of glacial retreat.

The second category of chronological control is termed 'secondary' data. These are samples from archives, typically lacustrine cores, that are not within the former course of the glacier. They provide indirect evidence for the chronology of glaciation, or glacially related climate change, but do not directly date glacial advance or retreat at a particular location. They are used as evidence for testing the chronology inferred from the primary radiocarbon data.

\subsection{Primary Chronological Control Samples}

The primary radiocarbon controls are listed in Table 1 . The locations of the samples are shown in Figure 1. They are divided into samples used to constrain the termination of the Tioga glaciation (i.e., maximum age constraint on the 1986 calibrationsamples), samples associated with the Tioga glaciation but not used as age constraintsand samples associated with the initiation and retreat of the Recess Peak glaciation. Both the original radiocarbon ages and contemporary calibrated ages are

given for each sample. Radiocarbon ages were converted to calibrated years using the IntCal13 data set, as implemented by the CALIB 7.1 program (Stuiver and Reimer, 1993; Reimer et al., 2013). Uncalibrated radiocarbon ages are reported as “ ${ }^{14} \mathrm{C}$ yr” and calibrated radiocarbon ages as "cal yr". Ages cited either as "years” or "ka” are inferred time points that are in calendar years. All ages are referenced to 1950. 


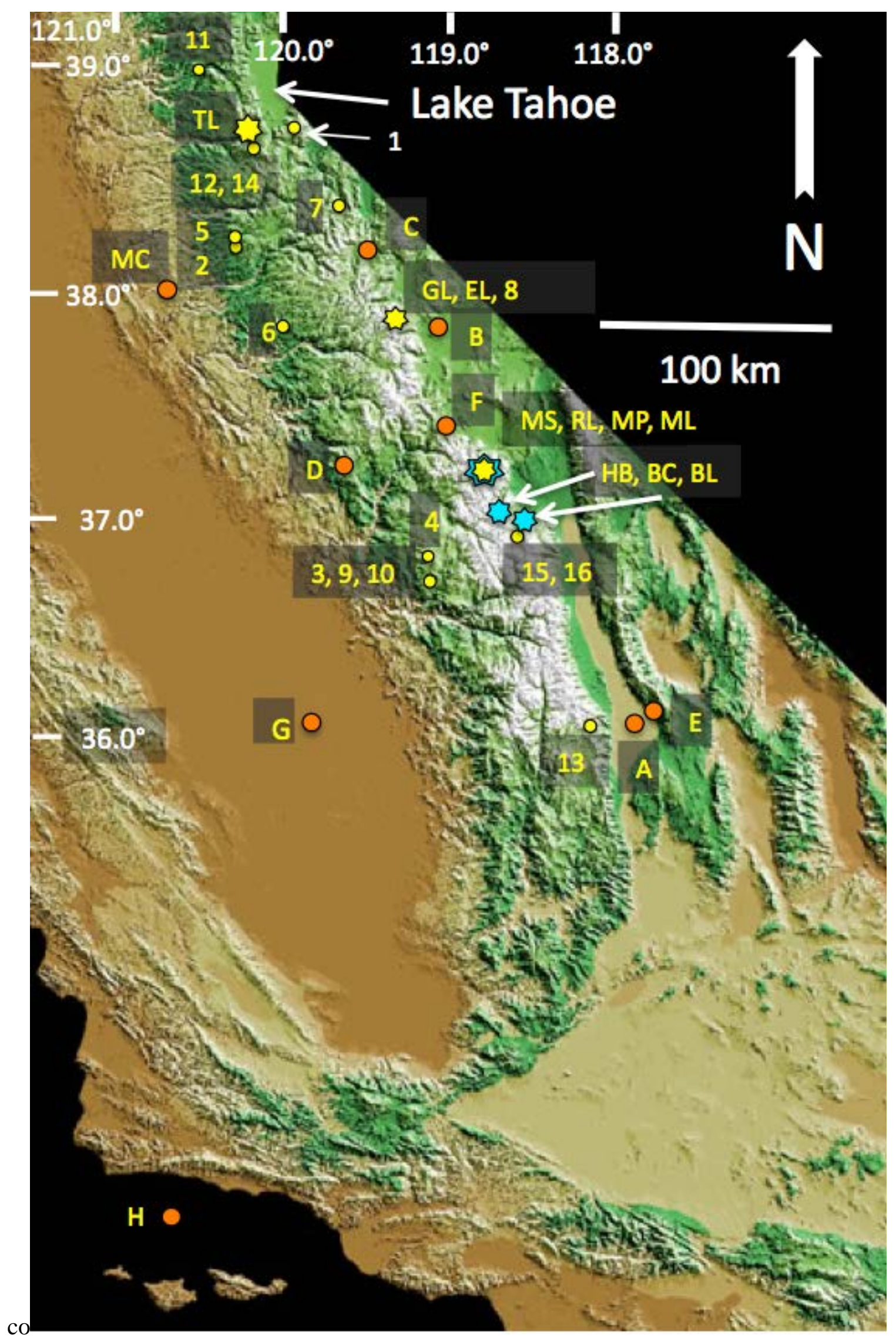


Figure 1. Southern and central Sierra Nevada, showing localities mentioned in the text. The ${ }^{10} \mathrm{Be}$ calibration sample localities are indicated by yellow stars and ${ }^{36} \mathrm{Cl}$ ones by blue stars. $\mathrm{TL}=$ Twin Lakes, $\mathrm{MC}=$ Moaning Cavern, $\mathrm{GL}=$ Greenstone Lake, $\mathrm{EL}=$ Ellery Lake, MS=Mount Starr, RL=Ruby Lake, MP=Morgan Pass, ML=Morgan Lake, HB=Humphreys Basin, BC=Bishop Creek, BL=Baboon Lakes. Primary age constraints are indicated by yellow circles, with numbers keyed to Table 1. Secondary age constraint sites are indicated by orange circles, with letters keyed to Table 2. The shading on the map corresponds to elevation, with white indicating greater than 3,000 $\mathrm{m}$ and brown less than $1,000 \mathrm{~m}$.

\{This figure to be given color on web version and black-and-white in print\}

Table 1. Primary radiocarbon control sites for Sierra Nevada glacial chronology.

\begin{tabular}{|c|c|c|c|c|c|c|c|c|c|c|}
\hline \multirow[b]{2}{*}{\begin{tabular}{|l} 
Control \\
Number
\end{tabular}} & \multirow{2}{*}{\multicolumn{2}{|c|}{ Radiocarbon Age }} & \multirow[b]{2}{*}{$\begin{array}{l}\text { Laboratory } \\
\text { Number }\end{array}$} & \multirow{2}{*}{\multicolumn{2}{|c|}{ Callibrated Age* }} & \multirow[b]{2}{*}{ Location } & \multirow[b]{2}{*}{ Elevation } & \multirow[b]{2}{*}{ Setting } & \multirow[b]{2}{*}{ Significance } & \multirow[b]{2}{*}{ Source } \\
\hline & & & & & & & & & & \\
\hline \multicolumn{11}{|c|}{ Samples Used to Constrain the End of the Tioga Glaciation } \\
\hline 1 & 17200 & 70 & & 20,740 & 110 & Grass Lake Bog & 2350 & Outside Tioga lateral moraine & Top of Tioga outwash sediment & Clark et al. (2003) \\
\hline 2 & 15565 & 820 & & 18,870 & 970 & Swamp Lake, N Fk Stanislaus R & 1957 & Inside Tioga recessional moraine & Top of outwash silt & Batchelder (1980) \\
\hline 3 & 15230 & 470 & Beta-52208 & 18,330 & 520 & Pond, N Fk Kings R & 1980 & Upstream of Tioga recessional & $\begin{array}{l}\text { Organic silt } \\
\text { s. }\end{array}$ & Clark et al. (1995) \\
\hline 4 & 13400 & 60 & & 16,130 & 100 & East Lake, N Fk Kings & 2864 & On crest of N Fork Kings River divide & $T_{p}$. glaclial rockflour, under laminated clay & Power (1998) \\
\hline 5 & 14750 & 500 & & 17,960 & 600 & Lake Moran, N Fk Stanislaus R & 2017 & Inside Tioga lateral moraine & Tephra (?) & Edlund and Byrne (1991) \\
\hline 6 & 13690 & 340 & Beta-27895 & 16,560 & 490 & Swamp Lake, Tuolumne R & 1554 & Inside Tiog recessional moraine & Organic sediments & Smith and Anderson (1992) \\
\hline $6 \mathrm{~b}$ & 14810 & 70 & Beta-202661 & 18,000 & 100 & Swamp Lake, Tuolumne R & 1554 & Inside Tloga recessilonal moraine & Organic sediments & Street et al. (2012) \\
\hline 7 & 13270 & 200 & & 15,950 & 290 & Highland Lakes, N Fk Stanislaus R & 2625 & In Tlopa accumulation zone & Organic silt: & Clark et al. (1995) \\
\hline $8 \mathrm{a}$ & 13090 & 60 & & 15,720 & 120 & Greenstone Lake, Tioga Creek & & In Tioga accumulation zone & On top of Tioga outwash & Clark (1997), Clarket al. (2003) \\
\hline \multicolumn{11}{|c|}{ Samples Associated with Tioga Glaciation But Not Used to Constrain Age } \\
\hline 9 & 11700 & 60 & CAMS11388 & 13,510 & 50 & Pond, N Fk Kings R & 1980 & Upstream of Tloga recessional moraine & Gyttja, $267 \mathrm{~cm}$ depth & Clark et al. (1995) \\
\hline 10 & 11690 & 60 & CAMS11376 & 13,510 & so & Pond, N Fk Kings R & 1980 & Upstream of Tioga recessional moraine & Gyttja, $259 \mathrm{~cm}$ depth & Clark et al. (1995) \\
\hline 11 & 11180 & 180 & Beta-56114 & 13,000 & 180 & Bunker Lake, Rubicon R & 1995 & Dammed by Tioga recessional moraine & ovtija & Edlund (1993) \\
\hline 12 & 11100 & 70 & USGS-1076 & 12.970 & 90 & Upper Echo Lake, Truckee R & 2260 & Upstream of Tloga recessional moraine & Organic slit & Adam (1985) \\
\hline 13 & 10640 & 160 & Beta-13569 & 12,560 & 170 & Cottonwood Lakes & 2880 & Upstream of Tloga recessional moraine & weed & Merger and Burbank (1986) \\
\hline$\Leftrightarrow$ & Interpolated age & & & $-15,800$ & & Swamp Lake, Tuolumne R & 1554 & Inside Tioga recessional moraine & Organic sediments & Street et al. (201) \\
\hline 14 & 9990 & 800 & A.545 & 11,600 & 1030 & Ospood Swamp, Upper Truckee R & 1985 & Dammed by Tioga recessional moraine & Peat, $30-40 \mathrm{~cm}$ above outwash & Adam (1967) \\
\hline \multicolumn{11}{|c|}{ nples Used to Constrain the Beginning and End of the Recess Peak Glaclation } \\
\hline 86 & 12190 & 60 & & 14,080 & 80 & Gree & 3091 & n of Recess Peak terminal & elow Recess Peak outwash silt & Clark (1997), Clarket al. (2003) \\
\hline 15 & 10880 & 60 & & 12,750 & 40 & & 3353 & in & Irganic silt overtying Recess $\mathrm{P}$ & Clark and Gillespie (1997) \\
\hline 16 & 11190 & 70 & & 13.060 & 70 & upper : & 3353 & cak terminal moraine & Gyttia overlying Recess Peak outwash & Clark and Gillesple (1997) \\
\hline
\end{tabular}

The calibrated ages used to constrain Tioga retreat and Recess Peak chronology, (Table 1) are shown in Figure 2(a). In this figure, the calculated glacial equilibrium line altitude (ELA) of each glacier as it retreated past the primary radiocarbon sample point is plotted as a function of the radiocarbon age. The ELA's were calculated using the toe-toheadwall altitude ratio (THAR) method (Charlesworth, 1957; Porter, 1964). A value of 
0.4 was used for the coefficient multiplying the toe-to-headwall altitude difference (Meierding, 1982). The "toe” altitudes were taken from the sample elevations and the headwall altitudes from a survey of topographic maps of the basins. The only exceptions were for Greenstone Lake, which was below the Recess Peak glacial limit and for which the terminal Recess Peak moraine elevation above the lake was used instead. Figure 2(a) also shows the THAR ELA's estimated for the various glacial advances in the San Joaquin River drainage, which has the best-mapped glacial deposits in the western Sierra Nevada (Birman, 1964). 

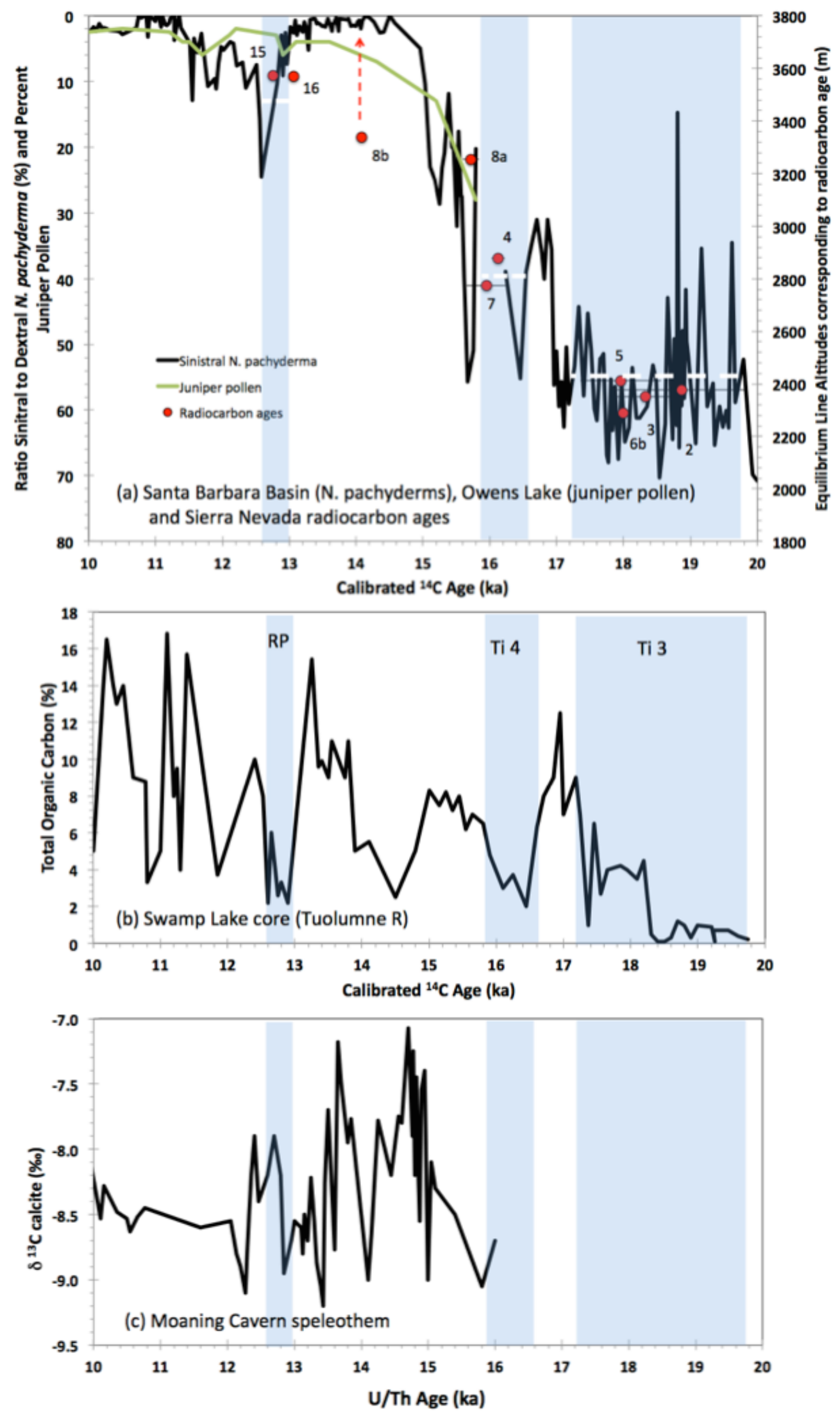
Figure 2. Comparison of paleoclimatic indicators in the Sierra Nevada region. (a) Estimated ELA for glacial terminus at the position of radiocarbon-dated basal sediments deposited after glacier retreat. See text for ELA estimation method. Numerals beside samples correspond to site numbers in Table 1. Dashed red arrow above sample 14 indicates that it provides only a minimum constraint on ELA. Also plotted are the percent of sinistral-coiling N. pachydermafrom ODP core 893A in the Santa Barbara Basin, from Hendy et al. (2002). The percentage of sinistral-coiling $N$.

pachydermaincreases as water temperature grows colder. On the same axis is plotted the percent juniper pollen from Owens Lake core OL84B, from Mensing (2001). Juniper is also an indicator of cold temperature. (b) Total Organic Carbon (TOC) content from cores from Swamp Lake, Tuolumne River, from Street et al. (2012). TOC increases with increasing temperature. (c) $\delta^{13} \mathrm{C}$ of calcite from a speleothem in Moaning Cavern, from Oster et al. (2009). $\delta^{13} \mathrm{C}$ increases with increasing temperature. See Figure 1 for locations of sites. Blue bars indicate timing of Sierra Nevada glacial advances, based on the Swamp Lake TOC record. White dashed lines across the blue shading in (a) show calculated ELA’s for glacial stages in the San Joaquin River drainage, based on mapping of terminal moraines by Birman (1964).

\{This figure to be given color on web version and black-and-white in print\}

The oldest sample included in the Tioga data set ("Control Number” 1) is 20,740 \pm 110 cal yr B.P., from Grass Lake Bog south of Lake Tahoe(Clark et al., 2003). This bog is at high elevation for thispart of the Sierra Nevada (2350 m), and located in an unusual situation where it was very close to, but outside of, the maximum Tioga moraine limit. The basal coarse sediment encountered in the core from this bog is therefore 
presumably outwash from the Tioga glacier, over its lateral moraine, when it was at or close to its maximum extent. It is not included in Figure 2 because the ELA cannot be calculated in a manner comparable with the other radiocarbon sites. The remaining samples in this set (Numbers 2-8) are from within the course of various Tioga glaciers and show a general decrease in ELA with decreasing age. This is the expected pattern, as discussed above. The only exception is Swamp Lake on the Tuolumne River, for which Clark et al. (1995) have reported an age of 16,560 \pm 490 cal yr B.P. that is anomalously young for its low elevation. This may be due to failure to penetrate through all of the late-stage outwash deposits, as discussed above. This hypothesis is supported by subsequent work by Street et al. (2012), who cored the same basin and obtained an age of about $18,000 \pm 100 \mathrm{cal}$ yr for the top of a thick section of near-zero organic carbon content; this is the data point (6b) plotted in Figure 2. Four other radiocarbon sites from low elevation (sites 2 through 5) are quite consistent with the Swamp Lake result, indicating that between 19 and $17 \mathrm{ka}$ the terminal position was relatively stable. This period of stability presumably corresponds with the Tenayastage of Sharp and Birman (1963), as well as the Tioga 3 advance of Phillips et al. (1996) and Phillips et al. (2009).

The three youngest samples from the top portion of Table 1 (16.3, 16.1, and 15.9 ka, at Highland Lakes, East Lake, and Greenstone Lake, respectively; also the highest elevation sites) provide chronological control for the final retreat of the Tioga glacier at high elevation. They are particularly significant as constraints on a minimum age for deglaciation because it is very unlikely that any measurable amount of organic matter could have been deposited in these basins prior to ice withdrawal. 
The ELA's for the samples from East Lake and Highland Lakes (numbers 4 and 7 in Table 1) approximately coincide with the climax of the Tioga 4 advance, based on comparison of their estimated ELA's with those for the prominent Tioga 4 terminal moraines mapped by Birman (1964)at Vermilion Valley on Mono Creek, a tributary of the South Fork of the San Joaquin River, and indicated on Figure 2(a) by the white dashed line across the blue "Ti 4" bar. Unlike Vermillion Valley, the East and Highland Lakes sites are not associated with prominent Tioga 4 moraines, probably because both of them are from drainages with headwall altitudes that were too low to produce large glaciers under the Tioga 4 ELA depression. Their headwall altitudes are2,900 $\mathrm{m}$ and 3,000 m, respectively, for East Lake and Highland Lakes, compared with a calculated ELA of 2,800 mfrom the Vermilion Valley moraines.

The youngest constraint on Tioga 4 retreat is provided by the Greenstone Lake sample (site 8a), at $15.7 \mathrm{ka}$. This lake is well above the elevation of the Tioga 4 terminal moraines (ELA of $\sim 3,600 \mathrm{~m}$ compared to Tioga 4 terminal ELA of $\sim 2,800 \mathrm{~m}$ ) and thus this sample dates the final Tioga 4 retreat. As described above, based on geomorphic and cosmogenic nuclide evidence, previous investigators have concluded that this final retreat was rapid. The age from Greenstone Lake should therefore constrain cosmogenic samples from elevations between the Tioga 4 terminal moraines and the Recess Peak moraines. In summary, based on this direct radiocarbon evidence for deglaciation chronology, the Tioga 4 maximum can be dated to about 16.2 ka and the midpoint of Tioga 4 retreat to about $15.7 \mathrm{ka}$.

The original investigators associated samples 9 through 14 with the termination of the Tioga glaciation, but are all at least 2,000 years younger that the best dates, listed 
above them in Table 1. Basal ages from cores that do not fully penetrate the glacial outwash sequence are limiting minimum ages and some anomalously young results are to be expected, for the reasons described above.

Samples 8b, 15, and 16 on Table 1 are high-elevation samples associated with the Recess Peak readvance. Samples $8 \mathrm{~b}$ is from Greenstone Lake, the same locality used as one of the definitive Tioga termination constraints. A date on organic-rich sediment stratigraphically below a layer of silt associated with Recess Peak outwash yielded an age of 14,080 $\pm 80 \mathrm{cal}$ yr B.P.(Clark et al., 1995; Clark et al., 2003). The termination of the Recess Peak advance has been dated to $13,060 \pm 70 \mathrm{cal}$ yr B.P. on organic-rich sediment overlying the outwash layer at the Baboon Lakes, in the Bishop Creek drainage (Clark and Gillespie, 1997). Two dates from different lakes (15 and 16 in Table 1) gave similar ages.In summary, these bounding radiocarbon ages constrain the Recess Peak advance to between 14.0 and $13.0 \mathrm{ka}$.

\subsubsection{Greenstone Lake and Ellery Lake}

Greenstone Lake is a particularly important locality, since it is one of the ${ }^{10} \mathrm{Be} /{ }^{26} \mathrm{Al}$ calibration sites and also has direct radiocarbon age control on both the Tioga deglaciation and the Recess Peak advance. The lake is at $3091 \mathrm{~m}$ and is on the west side of the Sierra Crest near Tioga Pass, draining into Lee Vining Creek, and ultimately Mono Lake. The area has been intensively studied by Douglas H. Clark of Western Washington University, who has cored Greenstone Lake and mapped the Recess Peak deposits in the basin. Figure 3 shows the location of the Recess Peak glacial limit in relation to the Nishiizumi sample site and Greenstone Lake. The calibration sample site is $\sim 100 \mathrm{~m}$ down-valley from the limit of the Recess Peak advance and is about 600 up-valley from 
Greenstone Lake. This proximity allows reliable correlation of the sample context in terms of the field mapping and the lacustrine sediment record.

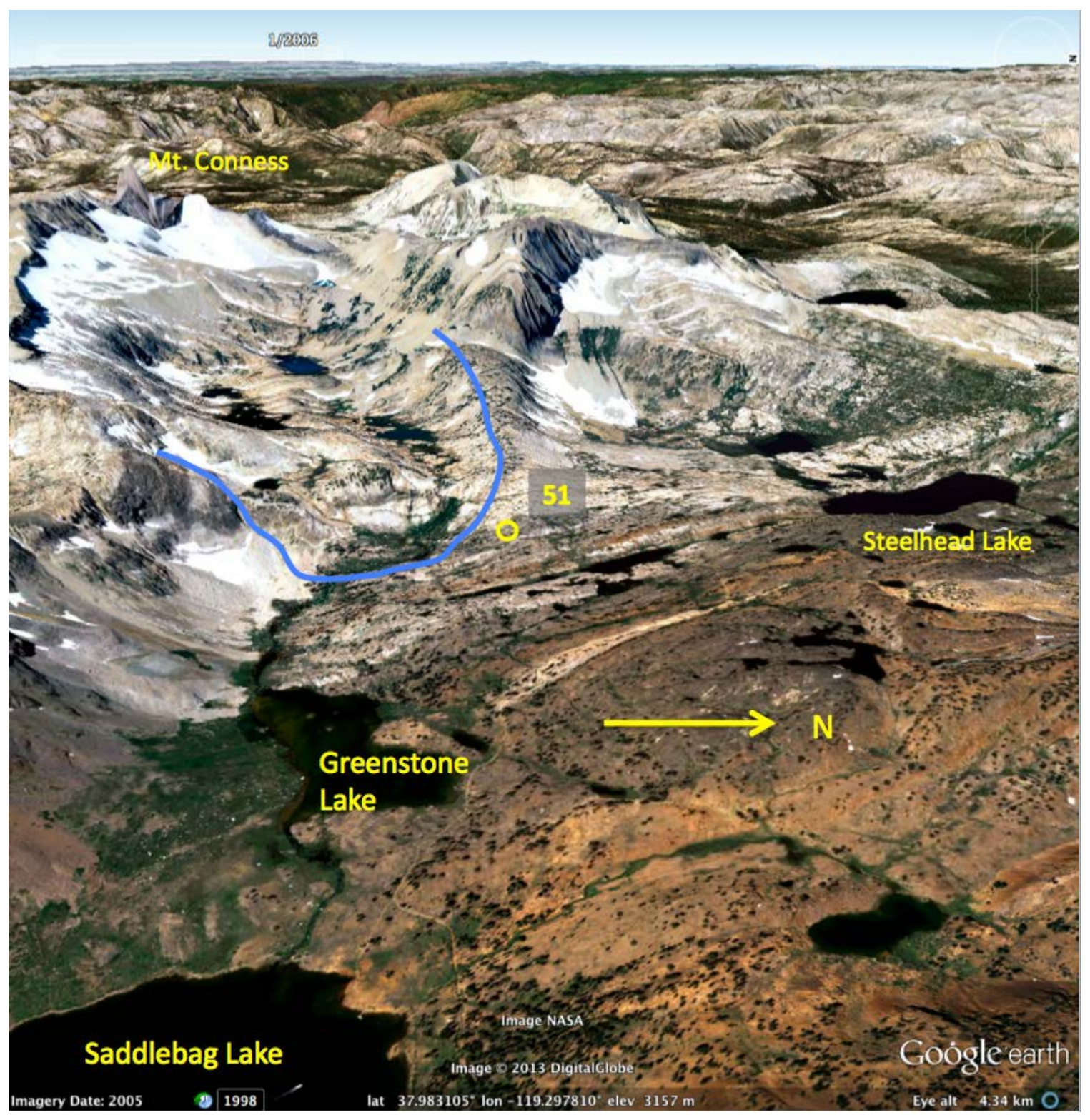

Figure 3. Perspective view, looking west, of ${ }^{10} \mathrm{Be} /{ }^{26} \mathrm{Al}$ calibration sample site number 51

(sample numbers W86-1 and 3), Greenstone Lake, and the Recess Peak glacial limit (in

blue). Glacial mapping from Clark et al. (2003). Distance across base of image is 1.5

$\mathrm{km}$. 
\{This figure to be given color on web version and black-and-white in print\}

Clark (1997) and Clark et al. (2003) reported on coring at Greenstone Lake. Porinchu et al. (2003) also cored Greenstone Lake, but their core stopped short of the period of interest with regard to deglaciation. The Holocene lacustrine sediment recovered by Clark and coworkers consisted of gyttja, with some tephra layers near the top of the sediment column. The gyttja was underlain by a thick layer of massive silt carried by the outwash streams from the late Pleistocene glaciers. The terminal Tioga and Recess Peak outwash layers were identified by means of high magnetic susceptibility and very low organic content, whereas the intervening interstadial sediment was characterized by somewhat higher organic matter and much lower magnetic susceptibility. Calibrated ${ }^{14} \mathrm{C}$ ages of $15,720 \pm 120 \mathrm{cal}$ yr and $14,080 \pm 80 \mathrm{cal}$ yr were obtained just above the top of the Tioga outwash and just below the base of the Recess Peak outwash, respectively. No ${ }^{14} \mathrm{C}$ age was obtained directly on top of the outwash layer at Greenstone Lake, but at the Baboon Lakes site in the Bishop Creek drainage, a date of $13,060 \pm 70 \mathrm{cal}$ yr was measured on sediment just above the Recess Peak outwash layer. This sequence of radiocarbon ages unambiguously constrains the chronology of calibration samples W86-1 and 3 in the vicinity of the sample site. As mentioned above, the chronology for this site is confirmed by additional radiocarbon ages from other Sierra Nevada study sites at similar elevation (especially Highland Lakes and Baboon Lakes; see Table 1). Based on these data, the best estimate for the exposure age of samples W86- 1 and 3 is between 16,000 and15,500 years (i.e., 15,750 $\pm 250 \mathrm{yr}$ ). The measured radiocarbon age of 14,040 cal yr for the start of the Recess Peak advance at Greenstone 
Lake provides a constraining minimum age for the calibration samples, but the actual age of exposure should be much closer to the Tioga deglacial age than to this minimum constraint.

\subsection{Secondary Chronological Control Samples}

\subsubsection{Secondary control on the timing of Tioga 4 glacial retreat}

As described above, there are many sites that are outside of the Tioga glacial limits, but that nevertheless yield information regarding the initiation and termination of glacial advances. Most of these are lacustrine sediment cores. A compendium of such results is presented in Table 2 and the locations of the study sites are shown in Figure 1.

Table 2. Secondary (indirect) radiocarbon age controls on Sierra Nevada glacial chronology.

\begin{tabular}{|c|c|c|c|c|c|c|c|c|c|}
\hline \multirow{2}{*}{\begin{tabular}{|c|} 
Site \\
Designotion
\end{tabular}} & \multirow[t]{2}{*}{ Event } & \multicolumn{2}{|c|}{ Radiocarbon Data } & \multicolumn{2}{|c|}{ Calibrated Age** } & \multirow[t]{2}{*}{ Site } & \multirow[t]{2}{*}{ Type of Sample } & \multirow[t]{2}{*}{ Evidence } & \multirow[t]{2}{*}{ Source } \\
\hline & & Age $(" \mathrm{l} C \mathrm{Cyr})$ & \pm 10 & (cal yr) & \pm 10 & & & & \\
\hline A & End Tioga & 12,760 & 70 & 15,200 & 100 & Owens Lake & Sediment core & Decrease in junper pollen and increase in $\delta^{32} 0$ & Benson et al. (1997) \\
\hline A & End Tiona & $\begin{array}{r}12,050 \\
-14,000\end{array}$ & & $\begin{array}{l}13,900 \\
16,500\end{array}$ & $\begin{array}{c}100 \\
1000\end{array}$ & Owens Lake & Sediment core & between these ages & Bischotfe al (1997) \\
\hline A & End Tloga & $\begin{array}{l}13,270 \\
12,650\end{array}$ & 70 & $\begin{array}{l}15,950 \\
15,050\end{array}$ & 120 & Owens Lake & Sediment core & $\begin{array}{l}\text { Decrease in juniper pollen and increase in artemisia } \\
\text { between these ages }\end{array}$ & Mensing (2001) \\
\hline в & End Tioga & 13,600 & 500 & 16,400 & 700 & Mono Lake & Sediment core & Increase in total inorganic $\mathrm{C}$, indicating cessation of rack flour & Benson et al. (1998) \\
\hline c & End Tioga & 12,700 & 40 & 15,140 & 70 & Hidden Lake & Sediment core & Increase in organic content and disappearance of cold-water chironomids & Potita (2006) \\
\hline $5 b$ & End Tioga & Interpolated & age & $-15,800$ & & Swamp lake & Sediment core & Increase in total organic carbon and other indicators & Street et al. (2012) \\
\hline 0 & End Tioge & 12,500 & -200 & 14,700 & -400 & Nichols Meadow & Sediment core & Increase in pollen flux and cessation of artemisia pollen & Koehler \& Andersn (1994) \\
\hline E & Beginning RP & 12,210 & 130 & 14,100 & 250 & Owens Lake & Shoreline sediments & Marked lacustrine transgression & Orme \& Orme (2008) \\
\hline F & Maximum RP & 11,490 & 50 & 13,340 & 50 & Starkweather $L k$ & Sediment core & Maximum of cold-water chironomids & MacDonald et al. (2008) \\
\hline $\mathrm{F}$ & End RP & 11,900 & 65 & 13,700 & 80 & Lake Barrett & Sediment core & Last cold-water chironomids & MacDonald et al. (2008) \\
\hline A & RP glaciation & 11,520 & 60 & 13,360 & 60 & Owens Lake & Sediment core & $\begin{array}{l}\text { Spike of decreased } \delta 180 \text { and total inorganic } \mathrm{C} \text { and increased } \\
\text { artemisia/chenoam pollen ratio }\end{array}$ & Benson et al. (1997) \\
\hline 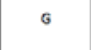 & $\begin{array}{l}\text { End Sierra } \\
\text { glaciation }\end{array}$ & 8,180 & 45 & 9,080 & 60 & Tulare Lake & Lake sediment & $\begin{array}{l}\text { Overlies glacial outwash fan } \\
\text { fon }\end{array}$ & Atwood et al. (1986) \\
\hline $\mathrm{H}$ & Entite Sequence & & & & & OOP CORe 893A & Marine sediment & Percent sinistral colling $N$. pochydermo with multiple radiocarbon ages & Hendy et al. (2002) \\
\hline
\end{tabular}

Data from several of the most informative secondary sites are shown in Figure 2.

In Fig. 2(a) two proxies are illustrated: the ratio of sinistral-to-dextral-coiling tests of the thermocline-dwelling foraminifera Neogloboquadrina pachyderma,from marine sediments cored by Ocean Drilling Program Hole 893A in the Santa Barbara Basin (Figure 1, H)off southern California (Hendy et al., 2002), and juniper as a percentage of 
total pollen from core OL84B from Owens Lake (Mensing, 2001). The sinistral-coiling form of $N$. pachyderma predominates in relatively cold waters and the dextral-coiling one in warm water; the ratio of the two has long been used as a semiquantitative proxy for ocean paleotemperature (Imbrie and Kipp, 1971). The N. pachyderma data from Hendy et al. (2002) were used, but they are plotted on the revised time scale of Kennett et al. (2008). The ODP 893A record is exceptionally detailed, with $\sim 50$ yr temporal resolution and 30 radiocarbon dates for age control in the 20 to $10 \mathrm{ka}$ interval.

Agreement is good between the direct radiocarbon chronologies of Tioga 3 and 4 glaciations from Table 1 and paleotemperatures inferred from N. pachyderma. As reviewed above, sites 2 through 5 in Table 1 were located several kilometers upstream from the Tioga terminal moraines (i.e., the Tioga 2 maximum advance; Phillips et al., 1996). This is consistent with the $N$. pachyderma coiling record, which shows maximum percentages of $N$. pachyderma (s.) at about 21 ka (Hendy et al., 2002). At about $17 \mathrm{ka}$ a decrease in $N$. pachyderma (s.) indicates a sudden warming, consistent with observed very significant retreat of glaciers at that time, both in the Sierra Nevada and worldwide (Schaefer et al., 2006; Phillips et al., 2009). This is followed by marked cooling starting at about $16.6 \mathrm{ka}$ and ending at $15.6 \mathrm{ka}$. This interval corresponds to the Tioga 4 advance, as demonstrated by radiocarbon ages from East Lake (site 4) and Highland Lakes (site 7). Unfortunately, data from the presumed peak of the cool interval is missing due to core loss.

The $N$. pachyderma (s.) record indicates that the Tioga 4 glacial episode ended abruptly at 15.6 ka. Direct dating of Tioga 4 retreat at Greenstone Lake (8a) is in good agreement, although the date there is slightly older (15.7 ka). The calculated ELA for 
this site $(\sim 3,600 \mathrm{~m})$ is well above that for the Tioga 4 maximum $(\sim 2,800 \mathrm{~m})$, indicating that glacial retreat must have started prior to $15.7 \mathrm{ka}$. Given uncertainties imposed in the marine chronology owing to the marine radiocarbon reservoir correction, the direct age determination on organic matter overlying Tioga outwash is to be preferred. The warming in the $N$. pachyderma record is abrupt, consistent with the geomorphic and cosmogenic dating evidence for rapid ice retreat that was described above. The deglacial warming shows one minor reversal at $\sim 15.25$ ka. This may be the oscillation responsible for the set of small moraines designated 'Hilgard' by Birman (1964) and discussed by Clark and Clark (1995).

Figure 2(a) also illustrates the record of percent juniper pollen from core OL84B from Owens Lake (Figure 1, A) measured by Mensing (2001). High percentages of juniper are characteristic of cold full-glacial climate in this core, but juniper is replaced by Artemisia and other desert shrubs under warm interglacial climate. The Owens Lake juniper pollen closely follows the paleotemperature indication provided by the $N$. pachyderma (s.) record, confirming that Santa Barbara Basin temperature record is relevant to Sierra Nevada paleoclimate.

One of the indirect paleoclimate records most closely connected to Sierra Nevada glaciation over the full period of interest is the total organic carbon content (TOC) of the Swamp Lake core (Tuolumne River, 5 in Figure 1) measured by Street et al. (2012) and shown in Figure 2(b). The variations in TOC reflect paleoenvironmental alternations. Cold episodes were characterized by an oligotrophic lake that was surrounded by sparse vegetation that resulted in increased detrital input. Warmer episodes resulted in increased lake productivity and increases in surrounding vegetation density that reduced detrital 
input (Street et al., 2012). The blue bands in all three panels of Figure 2 are defined by the low TOC intervals in the Swamp Lake core that appear to correlate with the known late Pleistocene glacial advances. For these intervals the timing of the TOC record and the Santa Barbara Basin N. pachyderma (s.) percentages agree well. The TOC record is also in good agreement with the reconstructed Sierra Nevada ELA's for the Tioga deglacial period. However, for the Recess Peak interval, the direct radiocarbon (primary) ages indicate that the Recess Peak advance was between 14 and 13 ka, whereas both the Swamp Lake TOC and the Santa Barabara N. pachyderma (s.) indicate that the timing was between 13.0 and $12.6 \mathrm{ka}$.

Figure 2(c) depicts variations in $\delta^{13} \mathrm{C}$ in calcite from a speleothem from Moaning Caverns (MC in Figure 1), which is a short distance below the glacial limit in the central western Sierra Nevada (Oster et al., 2009). The $\delta^{13} \mathrm{C}$ is likely controlled by plant respiration rate, with lighter values reflecting greater respiratory $\mathrm{CO}_{2}$ influx driven by increased precipitation, whereas heavy values reflect increased atmospheric $\mathrm{CO}_{2}$ and decreased respiratory $\mathrm{CO}_{2}$ resulting from drier climate (Oster et al., 2009). Dating was by U-series and should thus be independent of the various factors that can perturb radiocarbon dating. Unlike the other secondary records illustrated in Figure 2, the Moaning Cavern $\delta^{13} \mathrm{C}$ does contain a negative excursion at 13.4 ka, consistent with the direct radiocarbon age constraint on the Recess Peak glaciation. If these different types of paleoclimate records can be reconciled, this combination may indicate warm temperature accompanied by increased precipitation in the interval 13.5 to $13.3 \mathrm{ka}$. This would likely not have been conducive to glacial expansion. 
In addition to the paleoclimate records shown in Figure 2, several additional records are listed in Table 2. Two of these are also from Owens Lake. Detailed analysis of core OL84B by Benson et al. (1997) showed changes in environmental indicators that were consistent with a transition from a glacial to a non-glacial climate. These were bracketed by calibrated and additionally corrected radiocarbon ages of 15,200 and 13,900 years. Benson et al. (1997) subtracted a 600-year 'reservoir correction’ from their radiocarbon ages to account for residence time of dissolved carbon in the Owens Lake basin. While this correction appears well justified for the periods when Owens Lake was hydrologically closed, it is less clear that it is applicable for episodes when dissolved carbon was being flushed through the lake basin by overflow, such as during the Tioga glaciation. If this correction is not applied, the calibrated ages are in reasonable agreement with the analogous climate transitions discussed above, although slightly younger.

Bischoff et al. (1997) studied the chronology of rock-flour deposition in Owens Lake. Their results are not presented in sufficient detail to permit precise evaluation of the timing of the cessation of rock-flour deposition, but the authors provide an estimate of $\sim 14,000{ }^{14} \mathrm{C}$ yr in the text. This is equivalent to $\sim 16,500$ cal yr, slightly older than the results of the other two Owens Lake studies, but probably equivalent given the uncertainties. A reconstruction of lake surface elevations through the deglacial period by Bacon et al. (2006) indicated brief rises in lake level between 16.0 and $15.5 \mathrm{ka}$, between 14.5 and $13.0 \mathrm{ka}$, and between 12.2 and $11.2 \mathrm{ka}$. These cover the period of the Tioga 4 advance, the presumed period of the Recess Peak advance, and the Younger Dryas climate oscillation. 
A core study at Mono Lake, into which Lee Vining Creek and Greenstone Lake drain, by Benson et al. (1998), showed a strong increase in inorganic carbon content at about 16,400 cal yr, indicating a drop in lake level (although it must be noted that carbon storage in the closed Mono Lake basin is also an issue there for radiocarbon dating of lacustrine sediments). At Hidden Lake, north of Mono Lake, Potito et al. (2006) noted an increase in organic carbon content of the sediment and a decrease in cold-water chironomids at about 15,140 cal yr B.P.These results are in general supportive of the Tioga 4 deglaciation age estimate of 15.7 ka based on direct dating of glacial retreat and the indicators shown in Figure 2.

One additional Tioga site, at Nichols Meadow, which is just outside the Tioga glaciation limit on the western side of the Sierra Nevada, gave an increase in total pollen flux and decrease in Artemisia pollen at about 14,600 cal yr B.P (Koehler and Anderson, 1994). This is about 1,000 years younger than the age for Tioga 4 retreat indicated by the other chronologies reviewed above. This age corresponds to that of a very marked increase in both $\delta^{18} \mathrm{O}$ and $\delta^{13} \mathrm{C}$ in the speleothem from nearby Moaning Cavern(Oster et al., 2009), which these authors correlated to the beginning of the North Atlantic Bølling/Allerod interval, dated to $14.7 \mathrm{ka}$ in ice cores (Grootes and Stuiver, 1997). One possibility is that the vegetation, and hence pollen, at Nichols Meadow may have responded more strongly to a later, more pronounced warming than it did to an earlier, weaker warming that led to Tioga 4 retreat.

Several secondary sites also yield information on the age of the Recess Peak glaciation. At a shoreline outcrop above Owens Lake, Orme and Orme (2008) used radiocarbon to directly date a significant lacustrine transgression to $14,100 \pm 250 \mathrm{cal}$ yr 
B.P. This is consistent with the result from Greenstone Lake for what is presumably the same event: the initiation of the Recess Peak climate oscillation. In the OL84B core, Benson et al. (1997) found a spike of depleted $\delta^{18} \mathrm{O}$ and decreased inorganic carbon content, concurrent with an increased ratio of Artemisia to Chenopodiaceae + Amaranthus pollen, that would appear to be a result of changes in water balance and vegetation accompanying the Recess Peak glaciations. This location in the core was close to a radiocarbon age of approximately 13,360 cal yr B.P., if no reservoir correction is taken.

A lake core from Starkweather Lake (Fig. 1), located east of Mammoth Mountain, yielded somewhat equivocal results with regard to the timing of the Recess Peak advance (MacDonald et al., 2008). A dip in chironomid-inferred temperature is directly dated to $13,330 \pm 50 \mathrm{cal}$ yr. B.P., which is consistent with the chronological evidence for the Recess Peak advance at that time, as discussed above. However, it is accompanied by peaks in loss-on-ignition and $\delta^{13} \mathrm{C}$ of organic matter, generally used as indications of higher temperature, and the same study also shows a chironomid-inferred temperature peak, rather than a dip, at the same time period at nearby Barrett Lake.

At Moaning Cave in the Sierra Nevada foothills near the Stanislaus River, strong negative deviations in both $\delta^{18} \mathrm{O}$ and $\delta^{13} \mathrm{C}$ starting at $13.4 \mathrm{ka}$, peaking at $13.25 \mathrm{ka}$, and ending about $13.0 \mathrm{ka}$ (based on U/Th), record a cold cycle that appears to be correlative with the lacustrine records of the Recess Peak glaciation (Oster et al., 2009). The nearby TOC record from Swamp Lake, however, indicates warming (high TOC) during the interval 14 to 13 ka and marked cooling (low TOC) between 13.0 and 12.6 ka. Finally, a limiting minimum age of about 9,100 cal yr B.P. for cessation of deposition of glacial 
outwash (Atwater et al., 1986), at Tulare Lake in the San Joaquin Valley, is consistent with the chronologies presented above but does not add any constraints.

In summary, the ages obtained from secondary chronology sites are generally consistent with the radiocarbon dating of the final deglaciation from the Tioga 4 limit beginning at about 16,000 years ago and being concluded by about 15,500 years ago. The evidence from secondary chronologies for the timing of the Recess Peak advance is mixed. Many secondary sites are consistent with the direct radiocarbon dating of the between 14,000 and 13,000 years ago. Approximately an equal number, however, indicate either no cooling or warming during this interval, and instead support cooling within the classic Younger Dryas, 12.9 to $11.7 \mathrm{ka}$.

\subsection{Discussion of Chronology and Comparison with Regional Evidence}

The evidence discussed above for the chronology of the termination of the Tioga 4 glaciation supports an age assignment of $16.20 \pm 0.5 \mathrm{ka}$ for the Tioga 4 maximum and $15.75 \pm 0.5 \mathrm{ka}$ for the melting of the last remnants of the Tioga 4 glaciers past the high basins used for the CRONUS-Earth secondary data set. These ages could be considered somewhat controversial because they significantly predate the classical chronology for the beginning of deglaciation and rise of sea level at the Oldest Dryas/Bølling transition, dated in Greenland ice cores to 14.7 ka (Grootes and Stuiver, 1997). However, regional (at least) early warming has strong support from the $\delta^{18} \mathrm{O}$ record of planktic foraminifera in the Santa Barbara Basin. A well-dated (by ${ }^{14} \mathrm{C}$ ) and high-resolution data set measured by Hill et al. (2006) showed that the maximum in $\delta^{18} \mathrm{O}$ occurred at $16.75 \mathrm{ka}$, followed by 
an oscillation bringing the $\delta^{18} \mathrm{O}$ back to nearly-as-heavy values at $16.3 \mathrm{ka}$. Following this, the $\delta^{18} \mathrm{O}$ decreased steadily, until at $15.75 \mathrm{ka}$ it temporarily stabilized, at a value 1 per mille heavier than the peak at $16.3 \mathrm{ka}$. According to Hill et al. (2006), this corresponds to a temperature increase of $\sim 5^{\circ} \mathrm{C}$. The Santa Barbara Basin temperature record is consistent with the Sierra Nevada evidence discussed above for Tioga 4 glacial advance from 17.5 to $16.25 \mathrm{ka}$, followed by rapid retreat, with even high basins deglaciated by 16.0 to $15.5 \mathrm{ka}$. This chronology is supported by a survey of evidence by Schaefer et al. (2006)indicating that pre-Bølling initiation of glacial retreat was widespread in western North America and elsewhere, and by a global survey by Shakun et al. (2015) that indicates that the predominance of the retreat from LGM glacial positions was achieved prior to $15 \mathrm{ka}$.

Like the chronology for the Tioga 4 retreat, the ages discussed above to constrain the Recess Peak glacial advance also raise some concerns when compared to the generally accepted Northern Hemisphere deglacial chronology. Greenland ice cores, North Atlantic marine sediment cores, and continental records from the Atlantic margin all indicate that the last major glacial advance was associated with the Younger Dryas stade, 12.9 to 11.6 ka (Stuiver et al., 1995). A recent synthesis of radiocarbon ages from the western United States for a geographically widespread, but brief, cold and wet interval that was interpreted as the onset of the Younger Dryas indicates this climate transition corresponds to the classical Younger Dryas. Kennett et al. (2015) used Baysian statistics to examine the ages ofeight Younger-Dryas-inception sites in the west-central USA and Canada, in the context of 15 other similar sites at various locations around the world. They concluded that the dating was consistent with both the North American and 
the other sites being simultaneous and being the product of a climate transition between 12.835 and $12.735 \mathrm{ka}$, which is for practical purposes coincident with the initiation of the Younger Dryas in Greenland ice cores (Rasmussen et al., 2006).

An alternative candidate for the climatic driver of the Recess Peak advance is a brief cold snap termed the Intra-Allerød Cold Period (IACP) that has been identified inpollen profiles andGreenland ice cores between 13.25 and 13.07 ka (Stuiver et al., 1995), but any glacial advances associated with it in the North Atlantic area were completely overwhelmed by the subsequent much more severe and prolonged Younger Dryas advances. The sequence of events inferred from the radiocarbon chronology for the terminal Pleistocene glacial advance of the Sierra Nevada, as described above, would indicate that the major Sierra advance was during the IACP and that there was no advance of any significance during the Younger Dryas.

This inferred sequence of events is also not in complete agreement with independent climate records at the regional scale. An alkenone temperature record from marine sediments off the northern California coast shows pronounced cooling that is completely correlative with the Younger Dryas, but indicates relatively warm temperatures during the IACP (Barron et al., 2003). To the east, the oxygen-18 record from Fort Stanton Cave in New Mexico (Asmerom et al., 2010) shows pronounced Younger Dryas cooling, but no significant fluctuation during the IACP. Closer to the Sierra Nevada, in the Grand Canyon region, packrat midden records of the upper elevation limit of temperature-sensitive vegetation (Cole and Arundel, 2005) and stable isotopes in dated bat guano (Wurster et al., 2008) both support a strong Younger Dryas temperature reduction, but do not support one during the IACP. 
Within the Sierra Nevada there are also paleoclimate records that indicate substantial Younger Dryas cooling. Perhaps the most persuasive is the U/Th-dated stable isotope record from Moaning Cave, in the foothills near the Stanislaus River, illustrated in Figure 2(Oster et al., 2009). It does exhibit a very brief episode of light isotopes during the IACP, but the subsequent episode correlative to the Younger Dryas (12.5 to 10 $\mathrm{ka}$ ) is much longer and more negative. The paleolimnological studies by MacDonald et al. (2008) at Barrett and Starkweather Lakes (Secondary Site "F”, Table 2, Figure 1), show evidence of Younger Dryas cooling. The paleolimnological trends during the IACP are equivocal, with Starkweather indicating a brief and mild cooling and Barrett pronounced warming. The study by Street et al. (2012) at Swamp Lake (Tuolumne River) (Site 5b) shows an increase in total organic carbon, and thus presumably temperature, during the IACP and a decrease during the Younger Dryas.

In summary, while direct dating of lacustrine sediment layers correlated with the Recess Peak glaciation have yielded consistent and tightly constraining radiocarbon ages, the resultant chronology is not generally consistent with hemispheric, regional, or local paleoclimate records that seem to record much stronger cooling during the Younger Dryas than during the IACP. This discrepancy might be reconciled by the hypothesis that the temperature disparity was overcome by countervailing fluctuations in precipitation. If the IACP in the Sierra were relatively wet and the Younger Dryas very dry, ice advance might be greater during the shorter and less frigid IACP. I have chosen to rely on the direct dating from Greenstone and Baboon Lakes for the independent age assignment of $13.3 \pm 0.25 \mathrm{ka}$ for the Recess Peak advance, but acknowledge that other paleoclimate 
records at a range of distances from the cosmogenic-nuclide sample sites do not clearly support this assignment.

\section{Conclusions}

Abundant evidence is available to constrain the terminal Pleistocene glacial chronology of the Sierra Nevada, California. This includes direct evidence from radiocarbon dating of organic matter deposited in the paths of the retreating glaciers, and indirect evidence from lake cores, speleothems, and marine cores. There is upward scatter (i.e., toward younger ages) in the radiocarbon ages on organic matter overlying till; this is not unexpected and probably results most commonly from failing to penetrate through post-glacial outwash layers when augering cores. The oldest ages related to retreat of the Tioga 3 and 4 glaciers form a consistent pattern. A group of samples from close to the maximum extent of the Tioga 3 advance (ELA of about 2,400 m) date to 19 $18 \mathrm{ka}$. Another group is close to the ELA of the Tioga 4 maximum at $\sim 2,800 \mathrm{~m}$ and dates to a little older than $16 \mathrm{ka}$. The positions of the radiocarbon ages younger than this are consistent with rapid retreat of the Tioga 4 glacier. At the Greenstone Lake and Baboon Lakes localities, the Recess Peak till or outwash is sandwiched between calibrated ages of $14,080 \pm 80$ cal yr just below the base of the Recess Peak outwash, and 13,060 \pm 70 cal yr on top of the Recess Peak till (Clark and Gillespie, 1997; Clark et al., 2003).

Secondary chronological controls from lake cores, speleothems, and marine cores are generally in agreement with this primary dating on the glacial sequence. The most useful of these is ODP core 893A from the Santa Barbara Basin (Hendy et al., 2002). 
The ocean paleotemperature proxy of the ratio of sinistral to dextral curling $N$.

pachyderma was measured at $\sim 50$ year temporal resolution and the chronology controlled by 30 radiocarbon ages. The inferred paleotemperature variations closely match the shifts in the ELA reconstructed from the radiocarbon ages for glacial positions. This correspondence is reinforced by the high-resolution TOC record from Swamp Lake (Street et al., 2012), which shows low TOC in the intervals 19-18 and 17-16 ka. A record of $\delta^{13} \mathrm{C}$ in calcite from a speleothem from Moaning Caverns was dated by U series (Oster et al., 2009). It also shows similar patterns, although with more numerous oscillations. Other regional paleoclimate records, although often of lower temporal resolution and with various uncertainties affecting the chronology, are generally in agreement with the direct dating of the glacial record.

The various records that bear on the maximum and retreat of the Tioga glaciers are mutually supportive, but this is not the case for the Recess Peak advance. The direct radiocarbon dating, which appears to be quite reliable, indicates that this advance took place within the interval 14 to $13 \mathrm{ka}$. This is prior to the classical Younger Dryas stade from Greenland ice cores and sites around the North Atlantic. It is also not in agreement with many paleoclimatic records from the western United States that put the inception of the only significant late glacial cooling episode at about 12.8 ka. However, a significant proportion of the independent records from the vicinity of the Sierra Nevada do support a cooling in the 14 to 13 ka interval.

Based on assessment of all the evidence presented above, I propose the following chronology for the terminal Pleistocene deglaciation of the Sierra Nevada: Tioga 3 maximum at $18.5 \pm 0.5 \mathrm{ka}$, Tioga 4 maximum at $16.2 \pm 0.5 \mathrm{ka}$, midpoint of Tioga 4 
retreat at $15.75 \pm 0.5 \mathrm{ka}$, and Recess Peak maximum at $13.25 \pm 0.25 \mathrm{ka}$, while

acknowledging that regional evidence is contradictory with regard to the age of a

widespread climatic cooling that presumably correlates with the Recess Peak advance.

\section{Acknowledgements}

This portion of the CRONUS-Earth Project was funded by the National Science

Foundation through grant EAR-0345949 to Phillips. I thank Ingrid Hendy for the ODP 893A plankton data files.

\section{References}

Asmerom, Y., Polyak, V.J., Burns, S.J., 2010. Variable winter moisture in the southwestern United States linked to rapid glacial climate shifts. Nature Geoscience 3, 114-117.

Atwater, B.F., Adam, D.P., Bradbury, J.P., Forester, R.M., Mark, R.K., Lettis, W.R., Fisher, G.R., Gobalet, K.W., Robinson, S.W., 1986. A fan dam for Tulare Lake, California, and implications for the Wisconsin glacial history of the Sierra Nevada. Geological Society of America Bulletin 97, 97-109.

Bacon, S.N., Burke, R.M., Pezzopane, S.K., Jayko, A.S., 2006. Last glacial maximum and Holocene lake levels of Owens Lake, eastern California, USA. Quaternary Science Reviews 25, 1264-1282.

Barron, J.A., Heusser, L., Herbert, T., Lyle, M., 2003. High-resolution climatic evolution of coastal northern California during the past 16,000 years. Paleoceanography 18, doi:10.1029/2002PA000768.

Benson, L., Burdett, J., Lund, S., Kashgarian, M., Mensing, S., 1997. Nearly synchronous climate change in the Northern Hemisphere during the last glacial termination. Nature 388, 263-265.

Benson, L.V., Burdett, J.W., Kashgarian, M., Lund, S.P., Phillips, F.M., Rye, R.O., 1996. Climatic and hydrologic oscillations in the Owens Lake Basin and adjacent Sierra Nevada, California. Science 274, 746-749.

Benson, L.V., Lund, S.P., Burdett, J.w., Kashgarian, M., Rose, T.P., Smoot, J.P., Schwartz, M., 1998. Correlation of late-Pleistocene lake-level oscillations in Mono Lake, California, with North Atlantic climate events. Quaternary Research 49, 1-10. 
Birkeland, P.W., 1964. Pleistocene glaciation of the northern Sierra Nevada, north of Lake Tahoe, California. Journal of Geology 72, 810-825.

Birman, J.H., 1964. Glacial geology across the crest of the Sierra Nevada. Geological Society of America Special Paper 75, Boulder, Colorado, p. 80.

Bischoff, J.L., Menking, K.M., Fitts, J.P., Fitzpatrick, J.A., 1997. Climatic oscillations 10,000-155,000 yr B.P. at Owens Lake, California reflected in glacial rock flour abundance and lake salinity in Core OL-92. Quaternary Research 48, 313-325.

Blackwelder, E., 1931. Pleistocene glaciation in the Sierra Nevada and Basin ranges. Bulletin of the Geological Society of America 42, 865-922.

Bursik, M.I., Gillespie, A.R., 1993. Late Pleistocene glaciation of Mono Basin, California. Quaternary Research 39, 24-35.

Charlesworth, J.K., 1957. The Quaternary Era. Arnold, London.

Clark, D., Gillespie, A.R., Clark, M., Burke, R., 2003. Mountain glaciation of the Sierra Nevada, In: Easterbrook, D.J. (Ed.), Quaternary Geology of the United States: INQUA 2003 Field Guide Volume. Desert Research Institute, Reno, Nevada, pp. 287-312.

Clark, D.H., 1997. A new alpine lacustrine sedimentary record from the Sierra Nevada: Implications for late-Pleistocene paleoclimatic reconstructions and cosmogenic isotope production rates. Eos 78 (46), F249.

Clark, D.H., Bierman, P.R., Gillespie, A.R., 1995. New cosmogenic ${ }^{10} \mathrm{Be}$ and ${ }^{26} \mathrm{Al}$ measurements of glaciated surfaces, Sierra Nevada, California - They're precise but are they accurate? Geological Society of America Abstracts with Programs 27, A-170.

Clark, D.H., Clark, M.M., 1995. New evidence of late-Wisconsin deglaciation in the Sierra Nevada, California, refutes the Hilgard Glaciation. Geological Society of America Abstracts with Programs 27, 10.

Clark, D.H., Gillespie, A.R., 1997. Timing and significance of late-glacial and Holocene cirque glaciation in the Sierra Nevada, California. Quaternary International 38/39, 21-38.

Clark, M.M., 1976. Evidence for rapid destruction of latest Pleistocene glaciers of the Sierra Nevada, California. Geological Society of America Abstracts with Programs 8, 361-362.

Cole, K.L., Arundel, S.T., 2005. Carbon isotopes from fossil packrat pellets and elevational movements of Utah agave plants reveal the Younger Dryas cold period in Grand Canyon, Arizona. Geology 33, 713-716.

Evans, J.M., Stone, J.O.H., Fifield, L.K., Cresswell, R.G., 1997. Cosmogenic chlorine-36 production in K-feldspar. Nuclear Instruments and Methods in Physics Research B123, 334-340.

Fullerton, D.S., 1986. Chronology and correlation of glacial deposits in the Sierra Nevada, California, In: Sibrava, V., Bowen, D.Q., Richmond, G.M. (Eds.), Quaternary Glaciations in the Northern Hemisphere: Report of the International Geological Correlation Programme Project 24. Pergamon Press, Oxford, pp. 161169.

Gillespie, A.R., 1982. Quaternary glaciation and tectonism in the southeastern Sierra Nevada, Inyo County, California. California Institute of Technology, Pasadena, p. 695. 
Gillespie, A.R., Clark, D.H., 2011. Glaciations of the Sierra Nevada, California, In: Ehlers, J., Gibbard, P.L., Hughs, P.D. (Eds.), Quaternary Glaciations - Extent and Chronology: A Closer Look (Developments in Quaternary Science, Vol. 15). Elsevier, Amsterdam, pp. 447-463.

Gosse, J.C., Phillips, F.M., 2001. Terrestrial in-situ cosmogenic nuclides: Theory and application. Quaternary Science Reviews 20, 1475-1560.

Grootes, P.M., Stuiver, M., 1997. Oxygen 18/16 variability in Greenland snow and ice with $10^{3}$ to $10^{5}$-year time resolution. Journal of Geophysical Research 102, 26455-26470.

Hendy, I., Kennett, J.P., Roark, E.B., Ingram, B.L., 2002. Apparent synchroneity of submillennial scale climate events between Greenland and Santa Barbara Basin, California from 30-10 ka. Quaternary Science Reviews 21, 1167-1184.

Hill, T.M., Kennett, J.P., Pak, D.K., Behl, R.J., Robert, C., Beaufort, L., 2006. PreBolling warming in Santa Barbara Basin, California: surface and intermediate water records of early deglacial warmth. Quaternary Science Reviews 25, 28352845.

Imbrie, J., Kipp, N., 1971. A new micropaleontological method for quantitative paleoclimatology: Application to a late Pleistocene Caribbean core, In: Turekian, K.K. (Ed.), Late Cenozoic Glacial Ages. Yale University Press, New Haven, Conn., pp. 71-174.

Kennett, D.J., Kennett, J.P., West, G.J., Erlandson, J.M., Johnson, J.R., Hendy, I.L., West, A., Culleton, B.J., Jones, T.L., Stafford Jr, T.W., 2008. Wildfire and abrupt ecosystem disruption on California's Northern Channel Islands at the ÅllerødYounger Dryas boundary (13.0-12.9 ka). Quaternary Science Reviews 27, 25302545.

Kennett, J.P., Kennett, D.J., Culleton, B.J., Aura Tortosa, J.E., Bischoff, J.L., Bunch, T.E., Daniel, I.R., Erlandson, J.M., Ferraro, D., Firestone, R.B., Goodyear, A.C., Israde-Alcántara, I., Johnson, J.R., Jordá Pardo, J.F., Kimbel, D.R., LeCompte, M.A., Lopinot, N.H., Mahaney, W.C., Moore, A.M.T., Moore, C.R., Ray, J.H., Stafford, T.W., Tankersley, K.B., Wittke, J.H., Wolbach, W.S., West, A., 2015. Bayesian chronological analyses consistent with synchronous age of 12,83512,735 Cal B.P. for Younger Dryas boundary on four continents. Proceedings of the National Academy of Sciences 112, E4344-E4353.

Knopf, A., 1918. A geologic reconnaissance of the Inyo Range and the eastern slope of the Sierra Nevada, California, with a section on the stratigraphy of the Inyo Range by Edwin Kirk. U. S. Geological Survey Professional Paper 110, p. 130.

Koehler, P.A., Anderson, R.S., 1994. The paleoecology and stratigraphy of Nichols Meadow, Sierra National Forest, California, USA. Palaeogeography, Palaeoclimatology, Palaeoecology 112, 1-17.

MacDonald, G.M., Moser, K.A., Bloom, A.M., Porinchu, D.F., Potito, A.P., Wolfe, B.B., Edwards, T.W.D., Petel, A., Orme, A.R., Orme, A.J., 2008. Evidence of temperature depression and hydrological variations in the eastern Sierra Nevada during the Younger Dryas stade. Quaternary Research 70, 131-140.

MacGregor, K.R., Anderson, R.S., Waddington, E.D., 2009. Numerical modeling of glacial erosion and headwall processes in alpine valleys. Geomorphology 103, 189-204. 
Meierding, T.C., 1982. Late Pleistocene glacial equilibrium-line altitudes in the Colorado Front Range: A comparison of methods. Quaternary Research 18, 289-310.

Menking, K.M., Bischoff, J.L., Fitzpatrick, J.A., Burdette, J.W., Rye, R.O., 1997. Climatic/hydrologic oscillations since 155,000 yr B.P. at Owens Lake, California, reflected in abundance and stable isotope composition of sediment carbonate. Quaternary Research 48, 58-68.

Mensing, S.A., 2001. Late Glacial and early Holocene vegetation and climate change near Owens Lake, eastern California. Quaternary Research 55, 57-65.

Nishiizumi, K., Winterer, E.L., Kohl, C.P., Lal, D., Arnold, J.R., Klein, J., Middleton, R., 1989. Cosmic ray production rates of ${ }^{10} \mathrm{Be}$ and ${ }^{26} \mathrm{Al}$ in quartz from glacially polished rocks. Journal of Geophysical Research 94, 17907-17915.

Orme, A.R., Orme, A.J., 2008. Late Pleistocene shorelines of Owens Lake, California, and their hydroclimatic and tectonic implications, In: Reheis, M.C., Hershler, R., Miller, D.M. (Eds.), Late Cenozoic Drainage History of the Southwestern Great Basin and Lower Colorado River Region: Geologic and Biotic Perspectives. Geological Society of America Special Paper 439, Boulder, Colorado, pp. 207226.

Osborn, G., Bevis, K., 2001. Glaciation in the Great Basin of the Western United States. Quaternary Science Reviews 20, 1377-1410.

Oster, J.L., Montañez, I.P., Sharp, W.D., Cooper, K.M., 2009. Late Pleistocene California droughts during deglaciation and Arctic warming. Earth and Planetary Science Letters 288, 434-443.

Phillips, F.M., Argento, D.C., Balco, G., Caffee, M.W., Clem, J.M., Dunai, T.J., Finkel, R., Goehring, B., Gosse, J.C., Hudson, A., Jull, A.J.T., Kelly, M., Kurz, M.D., Lal, D., Lifton, N., Marrero, S.M., Nishiizumi, K., Reedy, R., Schaefer, J., Stone, J.O.H., Swanson, T., Zreda, M.G., 2015a. The CRONUS-Earth Project: A synthesis. Quaternary Geochronology, this volume.

Phillips, F.M., Hinz, M., Marrero, S.M., Nishiizumi, K., 2015b. Constraints on Cosmogenic Nuclide Production Rates by Samples from the Sierra Nevada, California: II. Sample sites and evaluation. Quaternary Geochronology, in revision.

Phillips, F.M., Zreda, M., Plummer, M.A., Elmore, D., Clark, D.H., 2009. Glacial geology and chronology of Bishop Creek and vicinity, eastern Sierra Nevada, California. Geological Society of America Bulletin 121, 1013-1033.

Phillips, F.M., Zreda, M.G., Benson, L.V., Plummer, M.A., Elmore, D., Sharma, P., 1996. Chronology for fluctuations in late Pleistocene Sierra Nevada glaciers and lakes. Science 274, 749-751.

Porinchu, D.F., MacDonald, G.M., Bloom, A.M., Moser, K.A., 2003. Late Pleistocene and early Holocene climate and limnological changes in the Sierra Nevada, California, USA inferred from midges (Insecta: Diptera: Chironomidae). Palaeogeography, Palaeoclimatology, Palaeoecology 198, 403-422.

Porter, S.C., 1964. Composite Pleistocene snowline of Olympic Mountains and Cascade Range, Washington. Geological Society of America Bulletin 75, 477-482.

Potito, A.P., Porinchu, D.F., MacDonald, G.M., Moser, K.A., 2006. A late Quaternary chironomid-inferred temperature record from the Sierra Nevada, California, with 
connections to northeast Pacific sea surface temperatures. Quaternary Research 66, 356-363.

Rasmussen, S.O., Andersen, K.K., Svensson, A.M., Steffensen, J.P., Vinther, B.M., Clausen, H.B., Siggaard-Andersen, M.L., Johnsen, S.J., Larsen, L.B., DahlJensen, D., Bigler, M., Röthlisberger, R., Fischer, H., Goto-Azuma, K., Hansson, M.E., Ruth, U., 2006. A new Greenland ice core chronology for the last glacial termination. Journal of Geophysical Research: Atmospheres 111, D06102.

Reimer, P.J., Bard, E., Bayliss, A., Beck, J.W., Blackwell, P.G., Bronk Ramsey, C., Buck, C.E., Cheng, H., Edwards, R.L., Friedrich, M., Grootes, P.M., Guilderson, T.P., Haflidason, H., Hajdas, I., Hatté, C., Heaton, T.J., Hoffmann, D.L., Hogg, A.G., Hughen, K.A., Kaiser, K.F., Kromer, B., Manning, S.W., Niu, M., Reimer, R.W., Richards, D.A., Scott, E.M., Southon, J.R., Staff, R.A., Turney, C.S.M., van der Plicht, J., 2013. IntCal13 and Marine13 radiocarbon age calibration curves 0-50,000 years cal BP. Radiocarbon; Vol 55, No 4 (2013), 1869-1887.

Rood, D.H., Burbank, D.W., Finkel, R.C., 2011. Chronology of glaciations in the Sierra Nevada, California, from ${ }^{10} \mathrm{Be}$ surface exposure dating. Quaternary Science Reviews 30, 646-661.

Schaefer, J.M., Denton, G.H., Barrell, D.J.A., Ivy-Ochs, S., Kubik, P.W., Andersen, B.G., Phillips, F.M., Lowell, T.V., Schluchter, C., 2006. Near-synchronous interhemispheric termination of the Last Glacial Maximum in mid-latitudes. Science 312, 1510-1513.

Shakun, J.D., Clark, P.U., He, F., Lifton, N.A., Liu, Z., Otto-Bliesner, B.L., 2015. Regional and global forcing of glacier retreat during the last deglaciation. Nat Commun 6.

Sharp, R.P., Birman, J.H., 1963. Additions to classical sequence of Pleistocene glaciations, Sierra Nevada, California. Geological Society of America Bulletin 74, 1079-1086.

Street, J.H., Anderson, R.S., Paytan, A., 2012. An organic geochemical record of Sierra Nevada climate since the LGM from Swamp Lake, Yosemite. Quaternary Science Reviews 40, 89-106.

Stuiver, M., Grootes, P.M., Brazuinas, T.F., 1995. The GISP2 $\delta^{18}$ O climate record of the past 16,500 years and the role of the sun, ocean, and volcanos. Quaternary Research 44, 341-354.

Stuiver, M., Reimer, P.J., 1993. Extended 14C data base and revised CALIB 3.0 14C age calibration program. Radiocarbon 35, 215-230.

Wurster, C.M., Patterson, W.P., McFarlane, D.A., Wassenaar, L.I., Hobson, K.A., Athfield, N.B., Bird, M.I., 2008. Stable carbon and hydrogen isotopes from bat guano in the Grand Canyon, USA, reveal Younger Dryas and 8.2 ka events. Geology 36, 683-688. 